Hybri d- Type Squar ami de- Fused Ami no Al cohol Or ganocat al yst $\mathrm{S}$ for Enant i osel ect i ve $\mathrm{N}$ tro- Al dol Reacti on of $\mathrm{N}$ tromethane with I sat i ns

\begin{tabular}{|l|l|}
\hline 著者 & $\begin{array}{l}\text { CHENAPURAM Nadhu, UMAREDDY Venkat a Subba } \\
\text { Reddy, SEK Chi gusa, OKUYAMA Yuko, KWON } \\
\text { Eunsang, UMAl Koj i, TOK WA M chi o, Takeshi t a } \\
\text { M t suhi ro, NAKANO H r ot o }\end{array}$ \\
\hline 杂隹誌名 & Eur opean Jour nal of Or gani c Chemi st ry \\
\hline 号 & 12 \\
\hline ページ & 1638 1646 \\
\hline 発行年 & $2017-03-27$ \\
\hline URL & ht t p: //hdl . handl e. net /10258/00009447 \\
\hline
\end{tabular}




\title{
Hybrid -Type, Squaramide-Fused Amino Alcohol Organocatalysts for Enantioselective Nitro-Aldol Reaction of Nitromethane with Isatins
}

\author{
Madhu Chennapuram, ${ }^{[a]}$ U. V. Subba Reddy, ${ }^{[a]}$ Chigusa Seki, ${ }^{[a]}$ Yuko Okuyama, ${ }^{[b]}$ Eunsang Kwon, ${ }^{*[c]}$ Koji \\ Uwai, ${ }^{[a]}$ Michio Tokiwa, ${ }^{[\mathrm{d}]}$ Mitsuhiro Takeshita, ${ }^{[\mathrm{d}]}$ and Hiroto Nakano**[a] \\ [a]* Division of Sustainable and Environmental Engineering, Graduate School of Engineering, Muroran Institute of \\ Technology, 27-1 Mizumoto-cho, Muroran 050-8585, Japan. \\ [b] Tohoku Medical and Pharmaceutical University, 4-4-1, Komatsushima, Aoba-ku, Sendai 981-8585, Japan \\ [c] Research and Analytical Center for Giant Molecules, Graduate School of Sciences, Tohoku University, 6-3, \\ Aoba, Aramaki, Aoba-ku, Sendai 980-8578, Japan
}

[d] Tokiwakai Group, 62 Numajiri Tsuduri-chou, Uchigo, Iwaki 973-8053, Japan.

\begin{abstract}
A series of new hybrid type squaramide-fused amino alcohol (SFAA) catalysts were synthesized and their catalytic efficiency in enantioselective nitro-aldol reaction of various isatins with nitromethane that afford the chiral 3-substituted 3-hydroxyoxindoles in excellent chemical yields (up to 99\%) and high enantioselectivities (up to $95 \%$ ee) is described. The resulting chiral 3-hydroxyoxindoles could be used as synthetic precursors for the synthesis of several natural products with a broad spectrum of fascinating biological activities.
\end{abstract}

\section{Introduction:}

Although the concept of utilizing organic molecules as catalysts started long ago, ${ }^{[1]}$ enantioselective organocatalysis has emerged as one of the most intensively investigated areas in organic chemistry since last two decades. ${ }^{[2]}$ Small organic molecules as catalysts could provide complex organic transformations with high levels of stereoselectivity in environmentally and economically friendly manner. Owing to their significance, the development of new organocatalysts and evaluation of their catalytic efficiency in organic transformations is still a challenging task. In recent years, we have been exploring the role of simple primary amino alcohols as new class of organocatalysts with distinctive properties such as easy synthesis, stability on exposure to air, potential for convenient alteration of the steric sites and ability to be used as bi-functional (enamine activation and non-covalent activation) catalysts. ${ }^{[3]}$ Organocatalysis using chiral hydrogen-bond (H-bond) donor catalysts, such as thioureas and squaramides, ${ }^{[4]}$ has expanded rapidly in the past few years. This type of catalysis now efficiently addresses the issue of the formation of multiple chiral centers with high stereoselectivitys. Nitro-aldol reaction (Henry reaction ${ }^{[5]}$ is one of the prominent coupling reactions between a carbonyl compound and a nitro alkyl compound bearing $\alpha$ - hydrogens, leading to the formation of a new $\mathrm{C}-\mathrm{C}$ bond with the concomitant generation of $\beta$-nitro alcohol, a new bi-functional moiety, which could further provide efficient routes to highly valuable and functionalized derivatives such as 1,2-amino alcohols or amino acids. ${ }^{[6]}$ Importantly, asymmetric aldol reaction of cyclic ketones generates a quaternary stereocenter, which is a challenging task in asymmetric synthesis. 


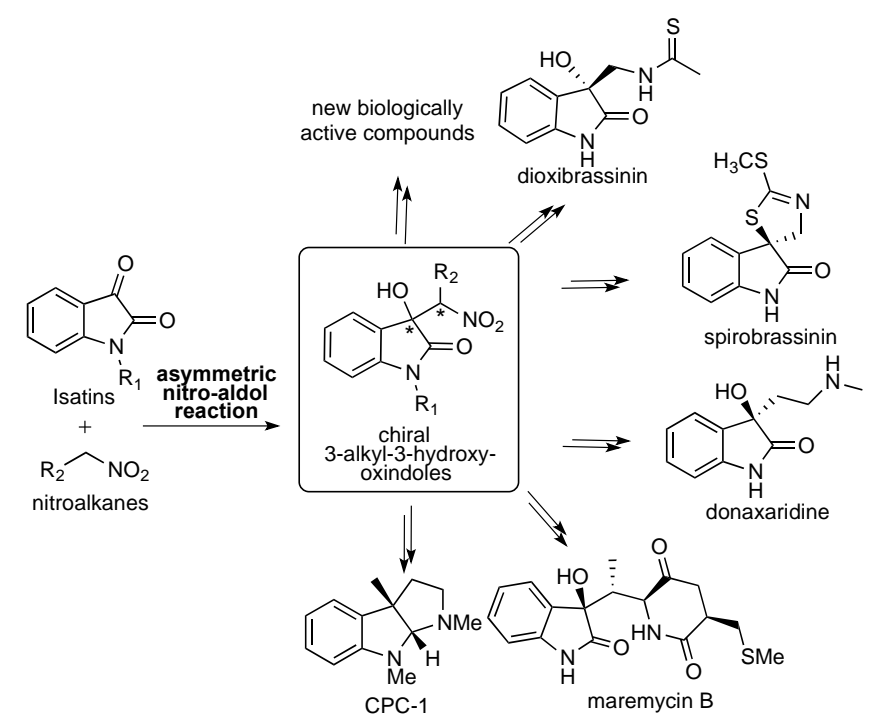

Scheme 1. Utility of Chiral 3-Alkyl-3-Hydroxyindoles

Specifically, asymmetric nitro-aldol reaction of isatins with nitroalkanes could provide chiral 3substituted 3-hydroxyoxindole core units ${ }^{[7]}$ with nitro functional group, which are important synthetic precursors for many biologically active natural products such as CPC-1 (antibacterial activity), ${ }^{[8 a]}$ maremycine B (cytotoxicity against K562 human leukemia cell lines), ${ }^{[8 b]}$ spirobrassinin (antifungal, antitumor and oviposition stimulation activity), ${ }^{[8 c]}$ donaxaridine (anticancer activity) ${ }^{[8 \mathrm{~d}, \mathrm{e}]}$ and dioxobrassinin (Scheme 1). Furthermore, these 3-hydroxyindoles could also be used as intermediates for newly designed drugs. Although there have been a few reports ${ }^{[9]}$ on the asymmetric nitro aldol reaction of isatins with nitroalkanes, all of them utilize the cinchona alkaloid derivatives as organocatalysts for this transformation. In continuation of our efforts towards expanding the scope of amino alcohols and their derivatives as organocatalysts, ${ }^{[3]}$ we herein focused on the synthesis of squaramide-fused amino alcohols $\mathbf{A}$ and $\mathbf{B}$, which have multiple hydrogen bonding sites and stereoinduction sites in the same molecule, and evaluated their catalytic activity for the nitro-aldol reaction of isatins with nitroalkanes. These simple amino alcohols with covalent and noncovalent hydrogen bonding sites in the same molecule work as efficient organocatalysts for many enantioselective reactions. ${ }^{[3]}$ In recent years, squaramide based catalysts containing two amino hydrogen bonding sites in four membered ring system have been explored rigorously. ${ }^{[10]}$ Being nitrogenated derivatives of squaric acid, squaramides are considered as vinylogous amides (Scheme 2, structure II), whereas, the corresponding urea and thiourea derivatives are normal (thio) amides (Scheme 2, structure I). Hence, the rotation of C-N single bond is restricted due to the delocalization of lone pair of electrons on nitrogen atom through the carbon-oxygen double bond of cyclobutenedione system and also further delocalization can occur due to the partially aromatic character of cyclobutanedione system. ${ }^{[1 \mathrm{a}]}$ Moreover, Takemoto ${ }^{[1 \mathrm{bb}]}$ and Rawal ${ }^{[11 c]}$ groups have calculated the distances between the two N-H groups for $N, N$ 'dimethylthiourea III and $N, N^{\prime}$-dimethylsquaramide IV to be approximately $2.13 \AA$ and $2.72 \AA$, respectively. And also, the square geometric structure of the cyclobutenedione ring also induces a convergent orientation of the $\mathrm{N}-\mathrm{H}$ groups, canting each by approximately $6^{\circ}$ (Scheme 2, structure 
VI). ${ }^{[11 c]}$ Because of all these peculiar properties, squaramide moieties could have greater linearity to make stronger hydrogen bonds with the substrates.

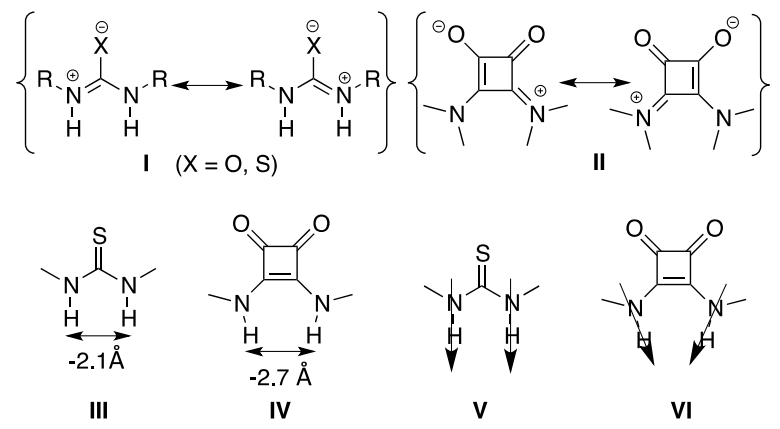

Scheme 2. Comparison of zwitterionic forms of the urea/thiourea and squaramide skeletons (I \& II), H-bond spacing distances (III \& IV), disposition of hydrogen bonds in $N, N^{\prime}$-dimethylthiourea and $N, N^{\prime}$-dimethylsquaramide (V \& VI).

Previously reported catalyst A containing two amino and one hydroxyl group as hydrogen bonding sites show efficient catalytic activity in the enantioselective allylation reaction. ${ }^{[12]}$ On the other hand, our newly designed catalyst B contains a cyclic tertiary amino group, which can act as Brønsted base as well as steric influence site along with two amino and one hydroxyl group which could make hydrogen bonding with both isatins and nitroalkanes (Scheme 3). Catalyst B could be easily prepared by the condensation of squarate methyl ester amide with the corresponding amino alcohols and due to the presence of multiple hydrogen bonding sites and steric factors in one molecule, it could show strong influence in controlling the stereoselectivity for the reaction of isatins with nitromethane as shown in the plausible transition state $\mathrm{X}$ (Scheme 3 ). Thus, isatins and nitromethane could be conformationally fixed by four hydrogen bonding interactions between the two amino groups on the squaramide site and two carbonyl groups on isatins, between the cyclic ammonium site and the oxygen atom on the nitro enolate moiety, and between the cyclic ammonium site and the hydrogen on the hydroxyl group in the ammonium alcohol intermadiate. And then, the reaction might proceed stereoselectively to afford the nitro-aldol product with high enantioselectivity.

Herein, we describe the synthesis of new type squaramide fused amino alcohol organocatalysts and their catalytic efficiency for the enantioselective nitro-aldol reaction of isatins with nitromethane as the first example using this class of organocatalysts to afford the corresponding aldol products with excellent chemical yields and enantioselectivities (up to $98 \%$, up to $95 \%$ ee). 


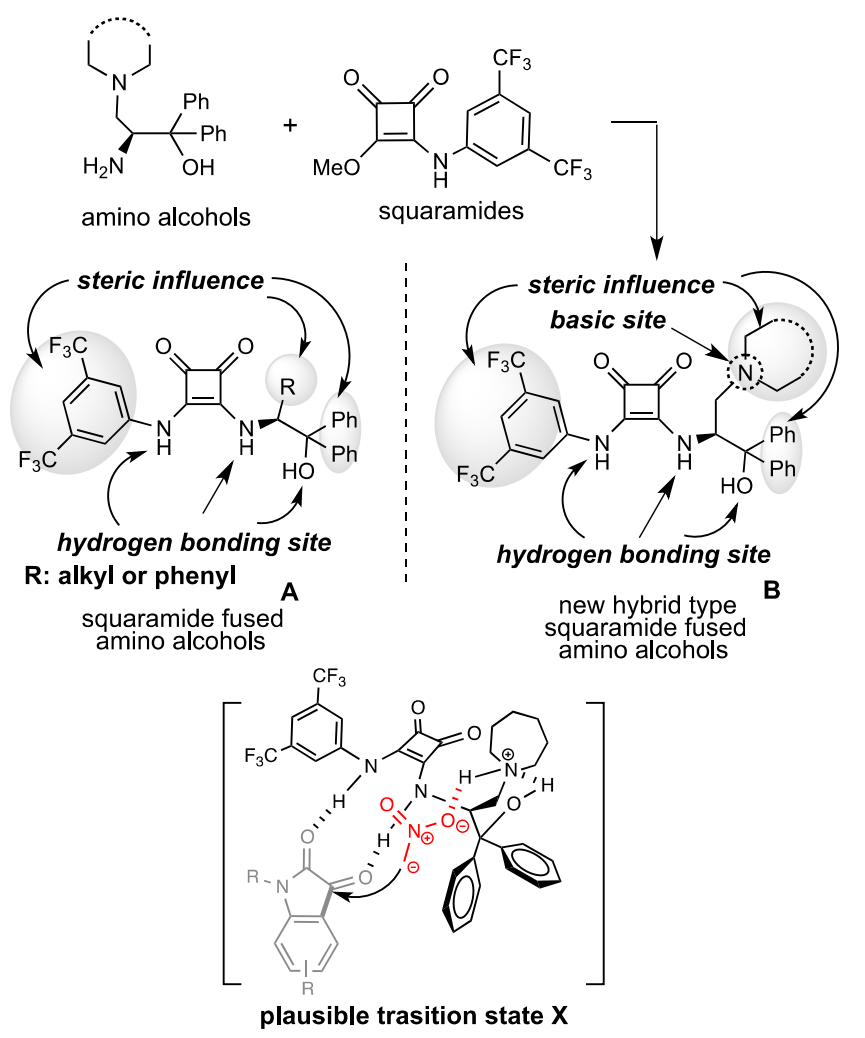

Scheme 3. Concept of catalyst design

\section{Results and Discussion}

The previous reported simple squaramide fused amino alcohol catalyst $\mathbf{4} \mathbf{c}^{[9]}$ and other new derivatives $\mathbf{4 a}, \mathbf{b}, \mathbf{d}$ were synthesized by the coupling of squarate monoester amide $\mathbf{3}$ with the corresponding $\beta$-amino alcohols 2a-d, which were obtained easily from commercial available amino esters 1a-d via Grignard reaction (Scheme 4)..$^{[3 \mathrm{~d}-\mathrm{f}]}$

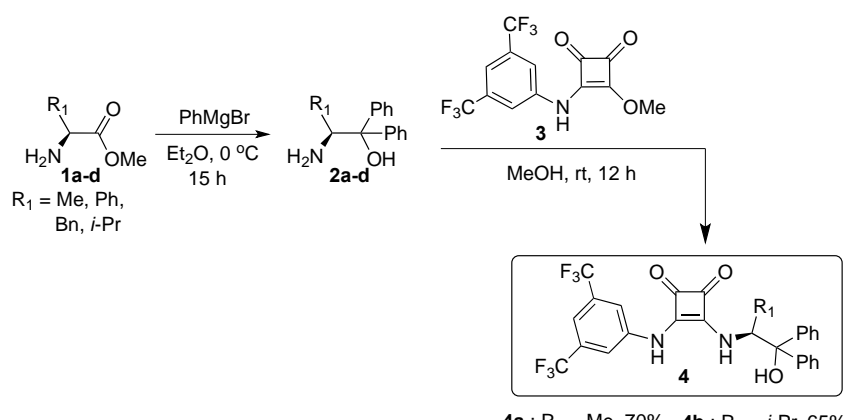

4a: $: \mathrm{R}_{1}=\mathrm{Me}, 70 \% \quad \mathbf{4 b}: \mathrm{R}_{1}=i-\operatorname{Pr}, 65 \%$ 4c : $R_{1}=P h, 64 \% \quad 4 d: R_{1}=B n, 59 \%$ 
Scheme 4. Synthesis of Usual Type of SFAA Catalysts 4a-d

With the catalysts 4a-d in hand, we desire to examine the catalytic activity of these catalysts in nitro-aldol reaction (Table 1). Initially, we carried out the reaction of simple isatin 5a with nitromethane $\mathbf{6}$ using catalyst $\mathbf{4 a}$ in THF at $0{ }^{\circ} \mathrm{C}$ in the absence of any basic additive. However, the expected aldol product 7a was not observed even after $48 \mathrm{~h}$ and the starting compound 5a could be recovered completely (entry 1). Then we hypothesized that addition of a basic additive might initiate the reaction. To implement this hypothesis, the basic additives such as TEA, DIPEA and DMAP were used in the course of reaction to abstract the proton from nitromethane (entries 2-4). By using these basic additives, the reaction was proceeded smoothly and the expected aldol product 7a was obtained, but the better results observed by using DMAP as additive (entry 4, 83\%, $38 \%$ ee). Then, different SFAA catalysts $\mathbf{4 b} \mathbf{b}$, were tested and each catalyst showed considerable catalytic activity and furnished the product $\mathbf{7 a}$ in good yields (up to 83\%), although the ee values were not satisfactory (entry 5-7, upto 32\% ee). Among the tested catalysts, $\mathbf{4 a}$ was found to be the best one to furnish the aldol product 7a in good chemical yield, though the enantioselectivity was not satisfactory. Different substituted isatins $\mathbf{5 b}$, and $\mathbf{5 c}$ were examined using catalyst $\mathbf{4 a}$ under the same reaction conditions. The reactions of $N$-methylated isatin $\mathbf{5 b}$ and $N$-benzylated isatin $\mathbf{5 c}$, afforded the respective aldol products $\mathbf{7 b}$ and $\mathbf{7 c}$ in moderate chemical yields and poor enantioselectivities (entries 8-9). A quick solvent screening was performed. The reaction proceeded efficiently in DCM and $\mathrm{CHCl}_{3}$ furnished the aldol products $\mathbf{7 a}$ in good yield, albeit in racemic form (entries 10-11). These results revealed that catalysts 4 a-d were inefficient to yield the aldol products with satisfactory enantioinduction and that a basic additive is necessary for the reaction to proceed. With these results in hand, we assumed that the introduction of tertiary amino group into the core structure of SFAA catalyst could improve the catalytic activity and enantioselectivity of the reaction.

Table 1. Nitro-Aldol Reaction of Isatins with Nitromethane Using Catalysts 4a-d

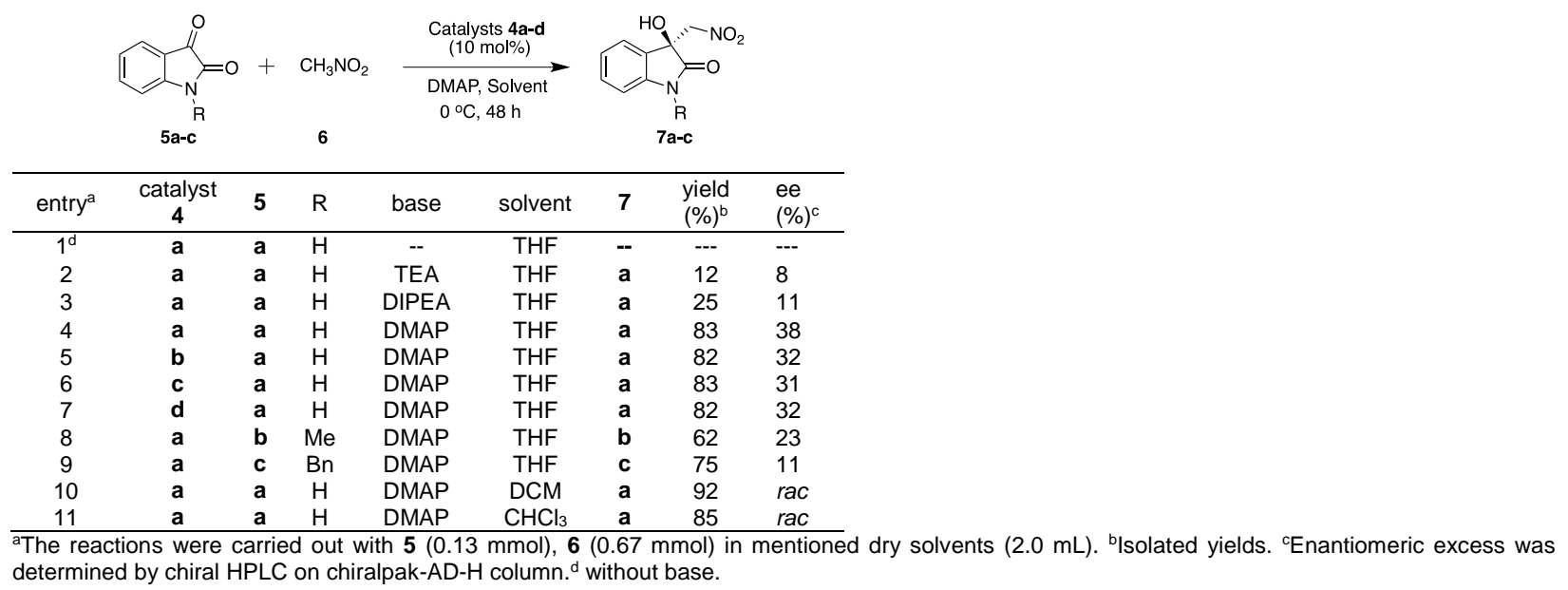

To test our hypothesis, we synthesized the new hybrid type SFAA catalysts 14a-e in few steps from commercially available $L$-serine methyl ester (Scheme 5). Grignard reaction of ammonium ester 8 using $\mathrm{PhMgBr}$ furnished the $\beta$-amino alcohol 9 in moderate yield. 


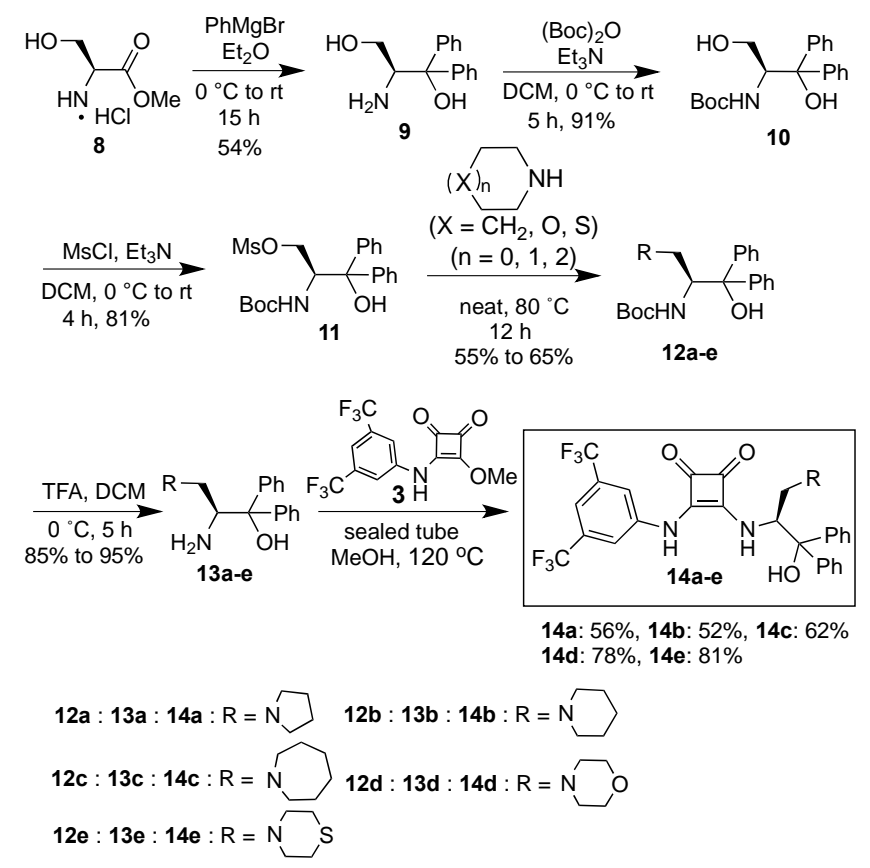

Scheme 5. Synthesis of New SFAA Catalysts 14a-e.

The free amino function of 9 was protected with Boc group by treatment with $(\mathrm{Boc})_{2} \mathrm{O}$ in the presence of $\mathrm{Et}_{3} \mathrm{~N}$ to afford 10, followed by the protection of primary hydroxyl group to result in the $O$-mesylated derivative $\mathbf{1 1}$ in good yield. Subsequently, mesyl function of $\mathbf{1 1}$ was replaced with various cyclic amines (pyrrolidine, piperidine, azepane, morpholine and thiomorpholine) under the neat reaction conditions to provide the compounds $\mathbf{1 2 a - e}$ in moderate to good yields. De-protection of Boc group of 12a-e by treating with TFA furnished 13a-e, and a further coupling with squarate monoester amide $\mathbf{3}$ afforded the targeted new type organocatalysts 14a-e in good overall yields (Scheme 5).

Next, we examined the catalytic activity of synthesized catalysts 14a-e using the best solvent i.e. THF (Table 2). As the first attempt, catalyst $\mathbf{1 4 a}$ bearing pyrrolidine ring system as a basic site was tested for the nitro-aldol reaction of simple isatin $\mathbf{5 a}$ with nitromethane $\mathbf{6}$ at $0^{\circ} \mathrm{C}$. Surprisingly, respective aldol product 7a was obtained in excellent chemical yield (99\%) with better enantioselectivity (64\% ee) (entry 1). Inspired by these results, we decided to examine the catalytic activity of other synthesized SFAA catalysts in this reaction. Catalyst $\mathbf{1 4 b}$ bearing piperidine ring system as a basic site afforded $\mathbf{7 a}$ with excellent chemical yield but with low enantioselectivity $(39 \%)$ (entry 2). The best enantioselectivity ( $81 \%$ ee) with good chemical yield (92\%) was obtained by using catalyst $\mathbf{1 4 \mathbf { c }}$ bearing azepane ring system (entry 3 ). On the other hand, other two catalysts $\mathbf{1 4 d}$ bearing morpholine and $\mathbf{1 4 e}$ bearing thiomorpholine ring systems, afforded the aldol product 7a in only trace amounts (entries 4-5). Fortunately, performing these reactions at room temperature successfully afforded the desired aldol product $\mathbf{7 a}$ in good chemical yields with moderate enantioselectivities (14d: 85\%, 61\% ee; 14e: 98\%, 59\% ee) (entries 6-7), but these results were not better than those obtained with $\mathbf{1 4 c}$. 
Table 2. Nitro-Aldol Reaction Using Catalysts 14a-e

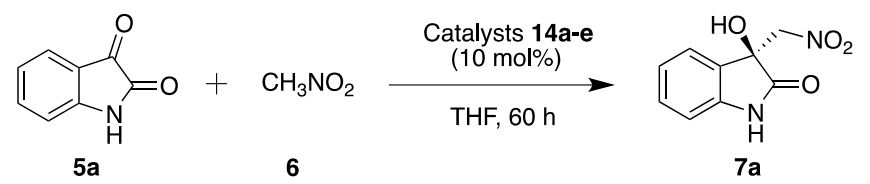

\begin{tabular}{ccccc}
\hline entry $^{\text {a }}$ & catalyst 14 & temp. $\left({ }^{\circ} \mathrm{C}\right)$ & yield $(\%)^{\mathrm{b}}$ & ee $(\%)^{\mathrm{c}}$ \\
\hline 1 & a & 0 & 99 & 64 \\
2 & b & 0 & 92 & 39 \\
3 & C & 0 & 92 & 81 \\
4 & d & 0 & trace & -- \\
5 & e & 0 & trace & -- \\
6 & d & RT & 85 & 61 \\
7 & e & RT & 98 & 59 \\
\hline
\end{tabular}

dry THF $(2.0 \mathrm{~mL})$. ' Isolated yields. 'Enantiomeric excess was determined by chiral HPLC on chiralpak AD-H column

We next inspected the effect of solvent, the molar ratio of catalyst, and reaction temperature (Table 3, entries 1-20). Changing the molar ratio of catalyst $14 \mathrm{c}$ to $5 \mathrm{~mol} \%$ and $20 \mathrm{~mol} \%$ also provided the aldol product 7a in good chemical yields and enantioselectivity ( 5 mol\%: 82\%, $74 \%$ ee, 20 mol\%: 93\%, 64\% ee), respectively (entries 1-2). At lower reaction temperature i.e $-20{ }^{\circ} \mathrm{C}$, both the chemical yield and enantioselectivity dropped to $70 \%$ and $78 \%$ ee respectively (entry 3 ). The use of non-polar aromatic solvents also gave 7a with excellent chemical yields (89-95\%), but completely in racemic form (entries 4-6). Furthermore, the reaction in chlorinated solvents and different ethereal solvents afforded 7a in good to excellent chemical yields (86-94\%) (except THP, in which case only trace amount of $\mathbf{7 a}$ was formed), but very poor to moderate enantioselectivities were observed (entries 7-12). Furthermore, the effect of polar solvents such as TFE, ACN, DMA, DMF, DMSO and MeOH were also investigated. Unfortunately, satisfactory chemical yields and enantioselectivities were not obtained (entries 13-18). The reaction was also conducted in water and in neat conditions (nitromethane used as solvent and reactant). Although, the product 7a was obtained in fairly good chemical yields, good enantioinduction was not observed (entries 19 and 20).

Table 3. Optimization of Nitro-Aldol Reaction Using Catalyst 14c

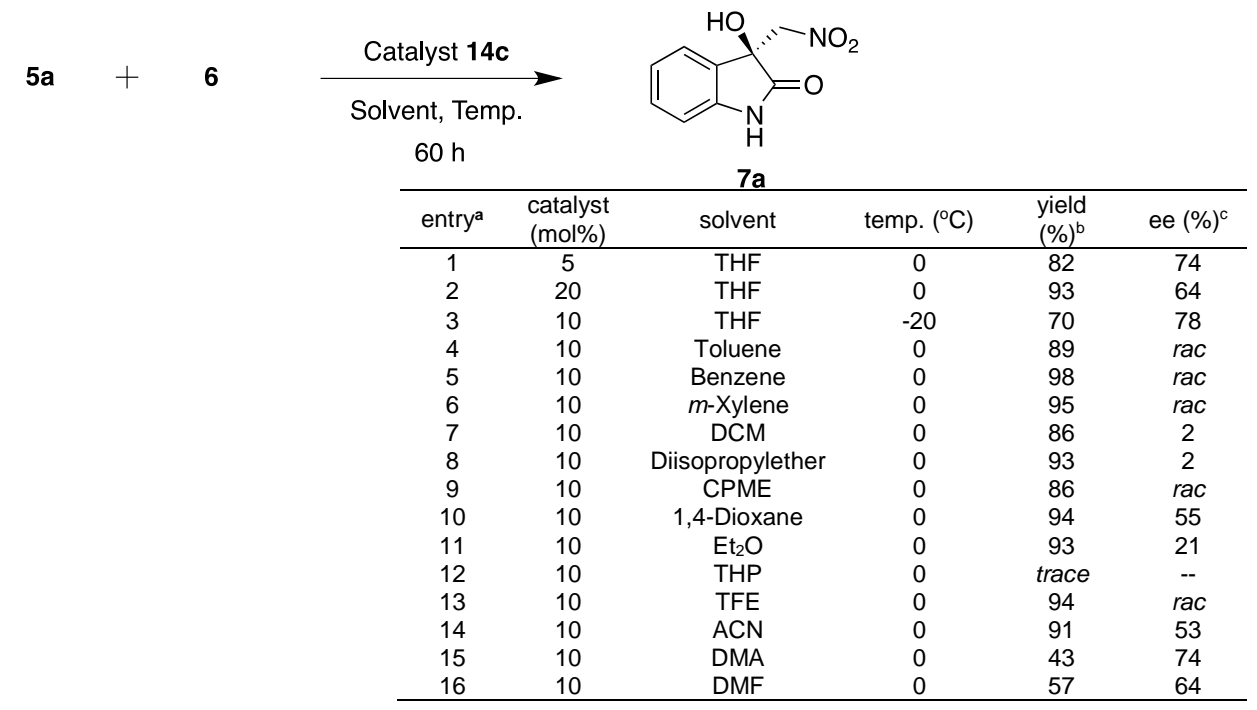




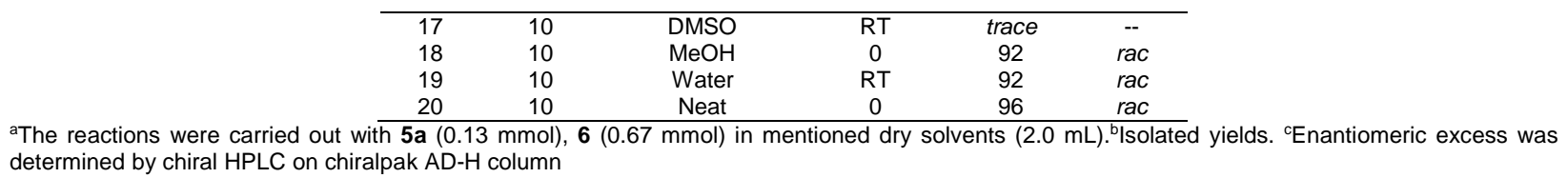

After rigorous screening of catalysts, catalyst loadings, additives, solvents and reaction temperatures, we decided to set the conditions in entry 3 of Table 2 as our optimal conditions for this reaction and started to explore the substrate scope. The generality of this protocol was fully demonstrated by evaluating a variety of isatins and nitromethane and the respective nitro-aldol products $7 \mathrm{~b}-\mathrm{k}$ were accomplished in good to excellent yields and poor to good enantioselectivities (Scheme 6). The reactions of $N$-alkylated isatins i.e $N$-methyl-isatin $5 \mathrm{~b}, N$-benzyl-isatin $5 \mathrm{c}$ and $N$ allyl-isatin $5 \mathrm{~d}$ with afforded the desired aldol products $7 \mathrm{~b}$-d, respectively, in excellent chemical yields $(95-98 \%)$ but with low to moderate enantioselectivity (26-67\% ee). On the other hand, the reaction of $\mathrm{N}$-Boc isatin 5e proceeded smoothly and accomplished the respective product 7e in good chemical yield ( $82 \%$ ) with excellent enantioselectivity (95\% ee). 5-Methyl-isatin 5 f provided the aldol product $7 \mathrm{f}$ in excellent chemical yield (96\%) with low selectivity (35\% ee). Moreover, only trace amount of the aldol product $7 \mathrm{~g}$ was obtained from the reaction of 5-NO 6 , although the exact reason was not clear. The use of halogenated isatins $5 \mathrm{~h}-\mathrm{k}$ provided the corresponding nitro aldol products $7 \mathrm{~h}-\mathrm{k}$ with fairly good to excellent chemical yields (89-97\%), but with moderate enantioselectivity $(52-64 \%$ ee). We also tried this protocol for superior nitroalkanes (Nitroethane, Nitropropane), but unfortunately does not yield the corresponding products with stereoselectivity (corresponding products were obtained in complete racemic form), although the reason was not clear.

Scheme 6. Substrate Scope of Nitro-Aldol Reaction

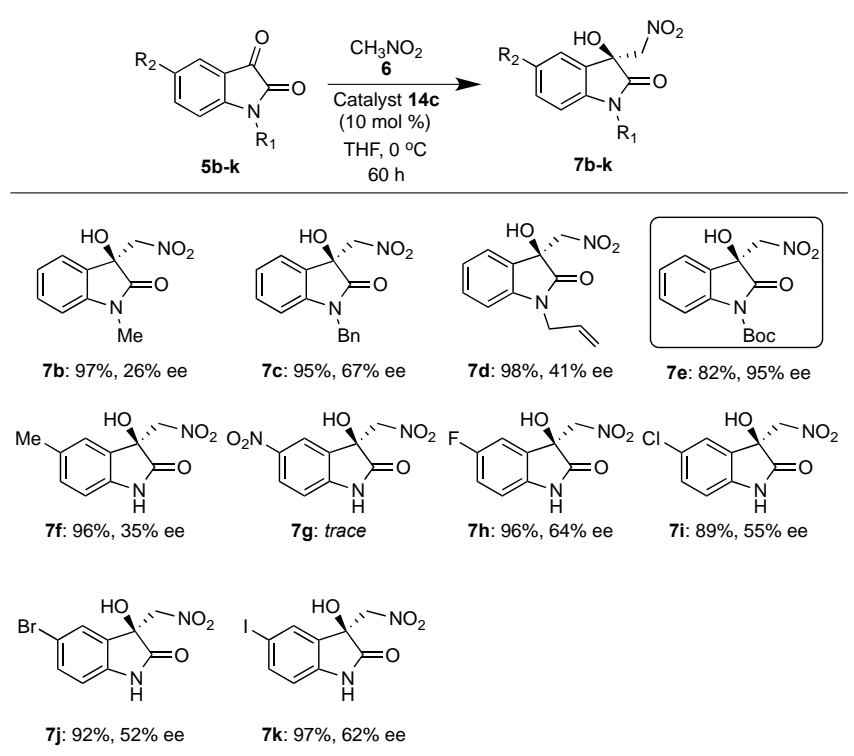


Finally, the enantioselective reaction mechanistic pathway of this reaction using our squaramide-fused amino alcohol catalyst 14c was considered based on both the high enantiopurity $(81 \%$ ee) of the chiral aldol product $(S)$-7a which was obtained from the reaction of isatin 5a with nitromethane $\mathbf{6}$ and the calculation analysis (a: natural bonding orbital $(\mathrm{NBO})^{[13]}$ analysis of the hydrogen bonding of simple squaramide VII with isatin 5a or nitrometane $\mathbf{6}$, b: the hydrogen bonding distance calculations of complexes $\mathbf{A}$ or $\mathbf{B}, \mathrm{c}$ : electron density of isatin $\mathbf{5 a}$ ) (Figure 1). Thus, (a) NBO analysis was performed subsequently on the optimized structures to quantify the donor-acceptor. The stabilization energies $\left(E^{(2)}\right)$ of intermolecular interactions of all complexes (complexes $\mathbf{A}$ and $\mathbf{B}$ ) were performed by using second order perturbation theory. As the calculation result, the stability of $\mathbf{A}\left(E^{(2)} / \mathrm{kcal} \cdot \mathrm{mol}^{-1}=1.56\right)$ was increased as compared with that of $\mathbf{B}\left(E^{(2)} / \mathrm{kcal} \cdot \mathrm{mol}^{-1}=0.25\right)$. This result might be consistent with the stability of the complexes. Furthermore, (b) the hydrogen bonding distance of complex A was also shorter than that of complex B. In addition, (c) the place of the highest electron density (Mulliken charge distribution) was on oxygen of amide in isatin $\mathbf{5 a}$.

From these knowledge, a model for the enantioselective reaction mechanistic pathway is proposed as follows (Scheme 7). First, the active methylene proton of nitromethane is abstracted by basic tertiary amino group on azepane ring in catalyst $\mathbf{1 4 c}$ to form nitro enolate, which might also induce the strong hydrogen bonding interaction between the hydrogen atom of the ammonium moiety on azepane ring in catalyst and oxygen atom of nitro enolate. Next, isatin 5a might fixed with catalyst $\mathbf{1 4} \mathbf{c}$ through two hydrogen bonds between two carbonyl oxygen atom on isatin 5a and two primary amino groups on squaramide site in catalyst. When isatin $\mathbf{5}$ makes the hydrogen bonding to catalyst, one carbonyl oxygen atom of amide on isatin $\mathbf{5 a}$ might binds with the hydrogen atom of amino group with 3,5-Bis(trifluoromethyl)phenyl group as an electron-withdrawing group on squaramide site in catalyst and other carbonyl oxygen atom on isatins 5a might binds with the hydrogen atom of another amino group on squaramide in catalyst. In addition, the side chain containing ammonium alcohol moiety on catalyst might be fixed by the hydrogen bonding interaction between hydrogen atom on the hydroxyl group and ammonium moiety on azepane ring on the side chain. Among the possible two transition states TS-I and TS-II, TS-II has less steric interaction than that of TS-I, which has strong steric repulsion between four membered squaramide skeleton and di-phenyl groups on catalyst. Hence the reaction might proceed via the transition state TS-II, in which nitroenolate coordinated to ammonium moiety on azepane ring could attack the isatin from the upper side ( $\mathrm{Si}$ face) leading to the formation of $(\mathrm{S})$-7a as major enantiomer, whereas minor isomer $(R)-\mathbf{7 a}$ might be obtained via the unfavorable transition state TS-I. 

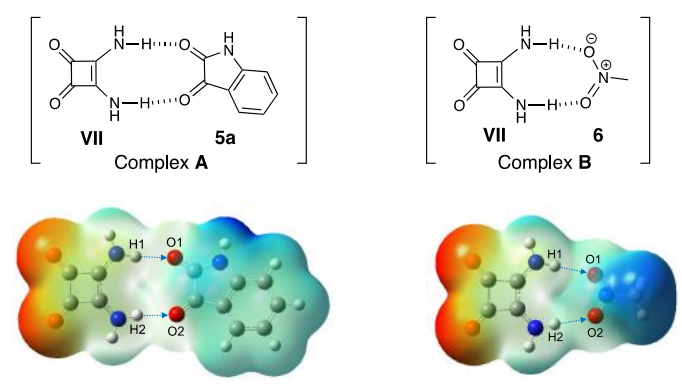

$E^{(2)} / \mathrm{kcal} \cdot \mathrm{mol}^{-1}=1.56$

$E^{(2)} / \mathrm{kcal} \cdot \mathrm{mol}^{-1}=0.25$
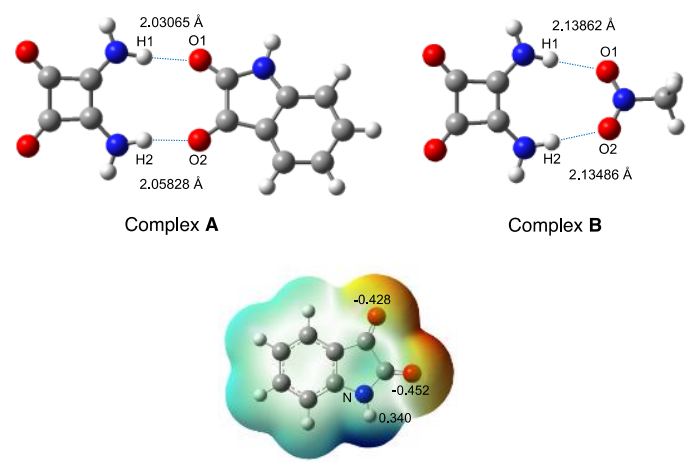

Mulliken Charge Distribution

Figure 1. (a) The calculated second order perturbation energies (E (2) / kcal, Eamol-1) of the second donor (H-bond donor of squaramides) and acceptor (Oxygenatoms of Isatins $\mathbf{5 a}$ and nitrate $\mathbf{6}$ ) interaction for the complexes $\mathbf{A}$ and $\mathbf{B}$, (b) the calculated hydrozen bond distances of the complexes $\mathbf{A}$ and $\mathbf{B}$, (c) The electron density map and Mulliken charge distribution of isatins $\mathbf{5 a}$.

Scheme 7. Plausible reaction course.
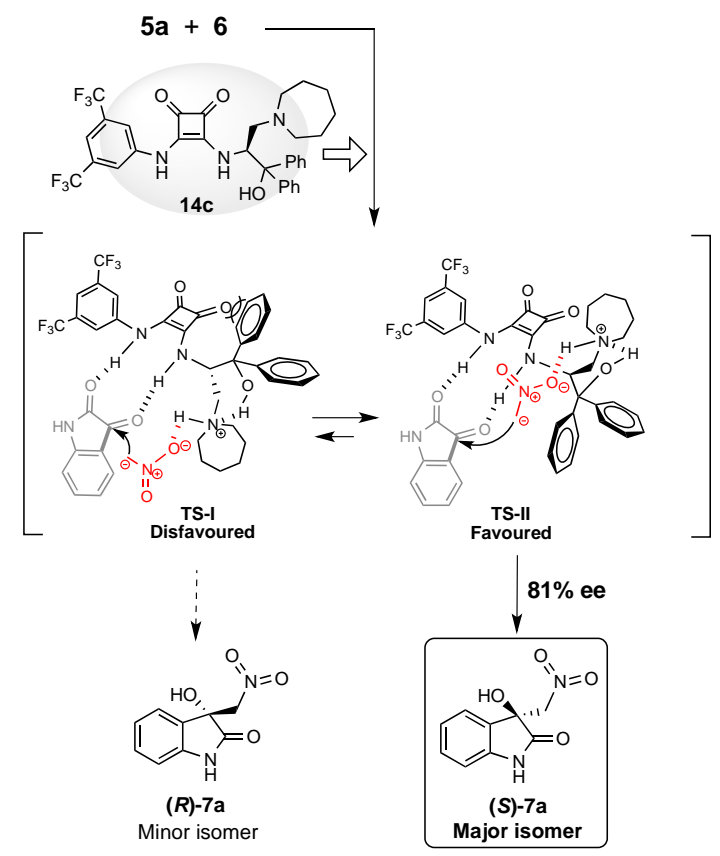


\section{Conclusions}

In summary, we have synthesized squaramide-fused amino alcohol (SFAA) catalysts 4a-d and newly designed SFAA catalysts 14a-e from commercial available amino esters via simple organic transformations and demonstrated their catalytic efficiency in the asymmetric nitro aldol reaction of various isatins and nitromethane. This protocol provides the chiral 3-substituted 3hydroxyoxindoles in excellent chemical yields (up to 99\%) and high enantioselectivities (up to 95\% ee). Catalyst $\mathbf{1 4} \mathbf{c}$ bearing azepane ring system as basic site showed best catalytic activity for this reaction among all synthesized catalysts. The resulted 3-alkylsubstituted 3-hydroxyoxindoles could be crucial intermediates for the synthesis of many significant biologically active scaffolds. The feasible mechanistic path of this reaction using our newly synthesized catalyst $\mathbf{1 4 c}$ was also explained by calculated the second order perturbation energies of second donor [H-bond donor of squaramide] and acceptor [oxygen atoms of isatin 5a and nitromethane 6] and hydrogen bond distances between catalyst $\mathbf{1 4 c}$ and isatin $\mathbf{5 a}$, and nitromethane $\mathbf{6}$.

\section{Experimental Section}

General Methods. All commercial reagents were purchased and used without further purification. All reactions were carried out under an argon atmosphere in flame-dried glassware with magnetic stirring. Thin layer chromatography (TLC) was performed on silica gel $60 \mathrm{~F}_{254}$ and analytes were detected using UV light $(254 \mathrm{~nm})$ and iodine vapor. Column chromatography was carried out on silica gel $60 \mathrm{~N}(40-100 \mu \mathrm{m})$ and preparative TLC was carried out on silica gel $60 \mathrm{~F}_{254}$. Melting points were measured using a micro-melting point apparatus. Infrared (IR) spectra were measured with a FT/IR spectrophotometer. ${ }^{1} \mathrm{H}-\mathrm{NMR}(500 \mathrm{MHz})$ and ${ }^{13} \mathrm{C}-\mathrm{NMR}(125 \mathrm{MHz})$ spectra were measured in $\mathrm{CDCl}_{3},\left(\mathrm{CD}_{3}\right)_{2} \mathrm{SO} .{ }^{1} \mathrm{H}-\mathrm{NMR}$ spectra data were reported as follows: chemical shifts in $\mathrm{ppm}$ from tetramethylsilane $(0.0 \mathrm{ppm})$ or the residual solvent as an internal standard $\left(\left(\mathrm{CD}_{3}\right)_{2} \mathrm{SO}\right.$; $2.50 \mathrm{ppm})$, integration, multiplicity $(\mathrm{s}=$ singlet, $\mathrm{d}=$ doublet, $\mathrm{t}=$ triplet, $\mathrm{q}=$ quartet, $\mathrm{dd}=$ doubletdoublet, $\mathrm{m}=$ multiplet and $\mathrm{br}=$ broad $)$, coupling constants $(\mathrm{Hz})$, and assignment. ${ }^{13} \mathrm{C}-\mathrm{NMR}$ spectra were measured with complete proton decoupling. Chemical shifts were reported in ppm from the residual solvent as an internal standard $\left(\mathrm{CDCl}_{3}: 77.16 \mathrm{ppm}\right)$. High performance liquid chromatography (HPLC) was performed using the chiral columns AD-H, AS-H $4.6 \mathrm{~mm}$ x $25 \mathrm{~cm}$ columns. Optical rotations were measured with a digital polarimeter. HRMS spectra were performed by EI and FAB using sector instruments.

General procedure for synthesis of catalysts 4a-d. To a stirred solution of squarate mono amide ester 3 (149 mg, $1 \mathrm{mmol}$ ) in dry MeOH (5 mL) was added corresponding $\beta$-aminoalcohol $2 \mathrm{a}$-d (1 $\mathrm{mmol}$ ) at room temperature and allowed the reaction mixture to stirred for $12 \mathrm{~h}$ at same temperature. After completion of reaction indicated by TLC, the excess $\mathrm{MeOH}$ was evaporated under reduced pressure results the crude reaction mixture, which was purified by flash column chromatography using Hexane:EtOAC (6:4) as eluent to afforded the targeted organocatalysts 4a-d as pure compounds in moderate to good yields. 
(S)-3-((3,5-Bis(trifluoromethyl)phenyl)amino)-4-((1-hydroxy-1,1-diphenylpropan-2yl)amino)cyclobut-3-ene-1,2-dione (4a). Pale yellow solid (MeOH). $170 \mathrm{mg}, 70 \%$ yield. m.p. $202-205^{\circ} \mathrm{C} .[\alpha]_{\mathrm{D}}^{24}=-38(\mathrm{c}=0.5, \mathrm{MeOH}) . \mathrm{IR}($ neat $)=3223,2980,1687,1417,1115,825 \mathrm{~cm}^{-1}$. ${ }^{1} \mathrm{H}$ NMR (500 MHz, DMSO- $\left.d_{6}\right): \delta 10.40(\mathrm{~s}, 1 \mathrm{H}), 8.03(\mathrm{~s}, 2 \mathrm{H}), 7.99(\mathrm{~d}, J=10.50 \mathrm{~Hz}, 1 \mathrm{H}), 7.62(\mathrm{~s}$, $1 \mathrm{H}), 7.51(\mathrm{t}, J=7.00 \mathrm{~Hz}, 3 \mathrm{H}), 7.40(\mathrm{t}, J=7.50 \mathrm{~Hz}, 2 \mathrm{H}), 7.26-7.20(\mathrm{~m}, 3 \mathrm{H}), 7.09(\mathrm{t}, J=7.50 \mathrm{~Hz}$, $1 \mathrm{H}), 6.42(\mathrm{~s}, 1 \mathrm{H}), 1.00(\mathrm{~d}, J=7.0 \mathrm{~Hz}, 3 \mathrm{H}), 0.83(\mathrm{~d}, J=7.00 \mathrm{~Hz}, 3 \mathrm{H}) .{ }^{13} \mathrm{C}$ NMR $(125 \mathrm{MHz}$, DMSO$\left.d_{6}\right): \delta 184.6,180.0,170.1,161.8,146.2,145.3,141.1,128.3,127.8,126.8,126.4,125.7,125.6$, 124.2, 122.1, 117.9, 114.6, 81.1, 63.6, 28.7, 22.3, 17.5. EI-MS m/z: $534(\mathrm{M})^{+}, 556.8(\mathrm{M}+\mathrm{Na})^{+}$. HRMS (EI) calcd for $\mathrm{C}_{27} \mathrm{H}_{20} \mathrm{~F}_{6} \mathrm{~N}_{2} \mathrm{O}_{3} \mathrm{~m} / \mathrm{z}: 534.1378$ (M) ${ }^{+}$found: 534.1390 .

(S)-3-((3,5-Bis(trifluoromethyl)phenyl)amino)-4-((1-hydroxy-3-methyl-1,1-diphenylbutan2-yl)amino)cyclobut-3-ene-1,2-dione (4b). White solid (ether). $150 \mathrm{mg}$, 65\% yield. m.p. 197$198{ }^{\circ} \mathrm{C} .[\alpha]_{\mathrm{D}}{ }^{24}=-647(\mathrm{c}=0.5, \mathrm{MeOH}) . \mathrm{IR}$ (neat) $=3215,2986,1696,1497,740 \mathrm{~cm}^{-1} .{ }^{1} \mathrm{H}$ NMR $\left(500 \mathrm{MHz}\right.$, DMSO- $\left.d_{6}\right): \delta 8.28(\mathrm{~s}, 1 \mathrm{H}), 8.21(\mathrm{~d}, J=11.00 \mathrm{~Hz}, 1 \mathrm{H}), 8.04(\mathrm{~d}, J=10.50 \mathrm{~Hz}, 1 \mathrm{H}), 7.50-$ $7.43(\mathrm{~m}, 4 \mathrm{H}), 7.34-7.23(\mathrm{~m}, 4 \mathrm{H}), 7.20-7.11(\mathrm{~m}, 1 \mathrm{H}), 5.76(\mathrm{~s}, 1 \mathrm{H}), 5.68(\mathrm{~s}, 1 \mathrm{H}), 5.12-5.10(\mathrm{~m}, 1 \mathrm{H})$, $4.40(\mathrm{~s}, 1 \mathrm{H}), 4.19(\mathrm{~s}, 1 \mathrm{H}), 0.93(\mathrm{~d}, J=7.00 \mathrm{~Hz}, 3 \mathrm{H}), 0.75(\mathrm{t}, J=6.50 \mathrm{~Hz}, 3 \mathrm{H}) .{ }^{13} \mathrm{C} \mathrm{NMR}(125 \mathrm{MHz}$, DMSO- $\left.d_{6}\right): \delta 189.8,182.4,177.3,173.1,146.8,130.2,129.3,128.8,128.3,128.1,127.9,127.5$, 126.6, 126.0, 125.8, 125.6, 125.5, 125.0, 80.5, 63.7, 28.5, 22.4, 17.7. EI-MS m/z: $562(\mathrm{M})^{+}$. HRMS (EI) calcd for $\mathrm{C}_{29} \mathrm{H}_{24} \mathrm{~F}_{6} \mathrm{~N}_{2} \mathrm{O}_{3} \mathrm{~m} / \mathrm{z}$ : $562.1691(\mathrm{M})^{+}$found: 562.1705 .

\section{(S)-3-((3,5-Bis(trifluoromethyl)phenyl)amino)-4-((1-hydroxy-1,1,3-triphenylpropan-2-}

yl)amino)cyclobut-3-ene-1,2-dione (4d). White solid (MeOH). $100 \mathrm{mg}$, 59\% yield. m.p. 253$255^{\circ} \mathrm{C} .[\alpha]_{\mathrm{D}}{ }^{24}=-25(\mathrm{c}=0.5, \mathrm{MeOH})$. IR (neat) $=3265,2986,1686,1446,855 \mathrm{~cm}^{-1} .{ }^{1} \mathrm{H}$ NMR $\left(500 \mathrm{MHz}, \mathrm{DMSO}-d_{6}\right): \delta 10.15(\mathrm{~s}, 1 \mathrm{H}), 8.05(\mathrm{~d}, J=10.00 \mathrm{~Hz}, 1 \mathrm{H}), 7.93(\mathrm{~s}, 2 \mathrm{H}), 7.66(\mathrm{~d}, J=7.50$ $\mathrm{Hz}, 2 \mathrm{H}), 7.60(\mathrm{~s}, 1 \mathrm{H}), 7.54(\mathrm{~d}, J=7.50 \mathrm{~Hz}, 2 \mathrm{H}), 7.46(\mathrm{t}, J=7.50 \mathrm{~Hz}, 2 \mathrm{H}), 7.29(\mathrm{t}, J=7.50 \mathrm{~Hz}$, $1 \mathrm{H}), 7.19(\mathrm{t}, J=7.50 \mathrm{~Hz}, 4 \mathrm{H}), 7.15-7.05(\mathrm{~m}, 4 \mathrm{H}), 6.62(\mathrm{~s}, 1 \mathrm{H}), 5.47-5.41(\mathrm{~m}, 1 \mathrm{H}), 2.83(\mathrm{~d}, J=$ $7.00 \mathrm{~Hz}, 2 \mathrm{H}) .{ }^{13} \mathrm{C}$ NMR $\left(125 \mathrm{MHz}\right.$, DMSO- $\left.d_{6}\right): \delta 183.8,179.6,169.6,160.9,145.4,145.1,141.0$, 137.9, 131.5, 131.2, 129.3, 128.6, 128.2, 127.9, 127.0, 126.4, 125.5, 124.2, 122.0, 117.6, 79.7, 62.2, 36.8. EI-MS m/z: $610(\mathrm{M})^{+}, 633(\mathrm{M}+\mathrm{Na})^{+}$. HRMS (EI) calcd for $\mathrm{C}_{33} \mathrm{H}_{24} \mathrm{~F}_{6} \mathrm{~N}_{2} \mathrm{O}_{3} \mathrm{~m} / \mathrm{z}$ : $610.1691(\mathrm{M})^{+}$found: 610.1697 .

General procedure for Synthesis of compounds 13a-e. Compound $11(1 \mathrm{mmol})$ compound was charged in $50 \mathrm{~mL}$ round bottomed flask and the corresponding cyclic amine $(5 \mathrm{mmol})$ was added drop-wise at room temperature. After 5 min stirring the temperature was raised to $70^{\circ} \mathrm{C}$ and allowed to stirred for $12 \mathrm{~h}$. After completion of the reaction, crude reaction mixture was purified by flash column chromatography using Hexane:EtOAc (7:3) as eluent to give the compounds 12ae $(55 \%$ - 65\%), Next, the compounds $12(1 \mathrm{mmol})$ compounds were dissolved in DCM (10 mL) followed by slow addition of TFA $(0.382 \mathrm{~mL}, 10 \mathrm{mmol})$ at $0{ }^{\circ} \mathrm{C}$ and stirred for $1 \mathrm{~h}$ at room temperature. After completion of reaction the residue was basified using with saturated aq. $\mathrm{NaHCO}_{3}$ solution and extracted in DCM $(3 \times 15 \mathrm{~mL})$ and the combined organic layers were washed with brine and dried over $\mathrm{Na}_{2} \mathrm{SO}_{4}$. The solvent was evaporated under reduced pressure to yield the resulted $\gamma$-tertiary amine aminoalcohols 13a-e $(85 \%$ - 95\%) as pure compounds without further purification. 
(S)-2-Amino-1,1-diphenyl-3-(pyrrolidin-1-yl)propan-1-ol (13a). Light yellow solid (Ether). $135 \mathrm{mg}, 90 \%$ yield. m.p. $113-115^{\circ} \mathrm{C} .[\alpha]_{\mathrm{D}}{ }^{24}=-74(\mathrm{c}=1.09$, EtOH $)$. IR (neat) $=2933,2803,1556$, 1448, $1355 \mathrm{~cm}^{-1} .{ }^{1} \mathrm{H}$ NMR $\left(500 \mathrm{MHz}, \mathrm{CDCl}_{3}\right): \delta 7.64(\mathrm{~d}, J=8.50 \mathrm{~Hz}, 2 \mathrm{H}), 7.53(\mathrm{~d}, J=8.50 \mathrm{~Hz}$, $2 \mathrm{H}), 7.33-7.25(\mathrm{~m}, 4 \mathrm{H}), 7.20-7.13(\mathrm{~m}, 2 \mathrm{H}), 3.92\left(\mathrm{q}, J_{1}=3.50,7.00 \mathrm{~Hz}, 1 \mathrm{H}\right), 2.76\left(\mathrm{q}, J_{1}=7.00\right.$, $13.00 \mathrm{~Hz}, 1 \mathrm{H}), 2.62-2.60(\mathrm{~m}, 2 \mathrm{H}), 2.42-2.40(\mathrm{~m}, 2 \mathrm{H}), 2.28\left(\mathrm{dd}, J_{1}=3.50,13.00 \mathrm{~Hz}, 1 \mathrm{H}\right), 1.76-$ $1.70(\mathrm{~m}, 4 \mathrm{H}) .{ }^{13} \mathrm{C} \mathrm{NMR}\left(125 \mathrm{MHz}, \mathrm{CDCl}_{3}\right): \delta 146.3,145.8,128.4,128.2 .126 .6,126.5,125.9$, 125.6, 79.9, 57.6, 55.1, 55.0, 23.7; FAB-MS m/z: $297(\mathrm{M}+\mathrm{H})^{+}$. HRMS (FAB) calcd for $\mathrm{C}_{19} \mathrm{H}_{25} \mathrm{~N}_{2} \mathrm{O}$ $\mathrm{m} / \mathrm{z}: 297.1967(\mathrm{M}+\mathrm{H})^{+}$found: 297.1963.

(S)-2-Amino-1,1-diphenyl-3-(piperidin-1-yl)propan-1-ol (13b). Pale yellow solid (Ether). 145 mg, $95 \%$ yield. m.p. $125-126{ }^{\circ} \mathrm{C} .[\alpha]_{\mathrm{D}}{ }^{25}=-66(\mathrm{c}=1.38$, EtOH). IR (neat) $=3432,2836,2321$, 1561, $1446 \mathrm{~cm}^{-1} .{ }^{1} \mathrm{H}$ NMR $\left(500 \mathrm{MHz}, \mathrm{CDCl}_{3}\right): \delta 7.60(\mathrm{~d}, J=7.50 \mathrm{~Hz}, 2 \mathrm{H}), 7.51(\mathrm{~d}, J=7.50 \mathrm{~Hz}$, $2 \mathrm{H}), 7.33-7.24(\mathrm{~m}, 4 \mathrm{H}), 7.20-7.15(\mathrm{~m}, 2 \mathrm{H}), 3.96\left(\mathrm{q}, J_{1}=4.50,6.50 \mathrm{~Hz}, 1 \mathrm{H}\right), 2.62-2.39(\mathrm{~m}, 3 \mathrm{H})$, 2.20-2.16 (m, 3H), 1.57-1.50 (m, 4H), $1.38(\mathrm{~s}, 2 \mathrm{H}) .{ }^{13} \mathrm{C}$ NMR (125 MHz, $\left.\mathrm{CDCl}_{3}\right): \delta 146.9,145.2$, 128.3, 128.2, 126.6, 126.5, 126.1, 125.8, 79.5, 59.1, 56.3, 54.0, 28.5, 26.3. FAB-MS m/z: 310 $(\mathrm{M}+\mathrm{H})^{+}$. HRMS (FAB) calcd for $\mathrm{C}_{20} \mathrm{H}_{27} \mathrm{~N}_{2} \mathrm{O} \mathrm{m} / \mathrm{z}: 311.2123(\mathrm{M}+\mathrm{H})^{+}$: found: 311.2126 .

(S)-2-Amino-3-(azepan-1-yl)-1,1-diphenylpropan-1-ol (13c). Pale yellow solid (Ether). $131 \mathrm{mg}$, $86 \%$ yield. m.p. $145-146{ }^{\circ} \mathrm{C} .[\alpha]_{\mathrm{D}}{ }^{23}=-40(\mathrm{c}=2.4, \mathrm{EtOH})$. IR (neat) $=3504,2933,2326,1615$, $1452 \mathrm{~cm}^{-1} .{ }^{1} \mathrm{H} \mathrm{NMR}\left(500 \mathrm{MHz}, \mathrm{CDCl}_{3}\right): \delta 7.60(\mathrm{~d}, J=8.50 \mathrm{~Hz}, 2 \mathrm{H}), 7.51(\mathrm{~d}, J=8.50 \mathrm{~Hz}, 2 \mathrm{H})$, 7.33-7.24 (m, 4H), 7.21-7.155 (m, 2H), $3.92\left(\mathrm{q}, J_{1}=4.50,7.50 \mathrm{~Hz}, 1 \mathrm{H}\right), 3.71(\mathrm{~s}, 3 \mathrm{H}), 2.69-2.65(\mathrm{~m}$, $2 \mathrm{H}), 2.57-2.52(\mathrm{~m}, 3 \mathrm{H}), 2.48\left(\mathrm{dd}, J_{1}=4.50,13.50 \mathrm{~Hz}, 1 \mathrm{H}\right), 1.63-1.56(\mathrm{~m}, 5 \mathrm{H}) .{ }^{13} \mathrm{C}$ NMR $(125$ $\left.\mathrm{MHz}, \mathrm{CDCl}_{3}\right): \delta 146.3,145.5,128.4,128.3,127.3,126.6,126.1,125.7,79.8,59.9,56.8,54.5,28.0$, 27.1. FAB-MS m/z: $325(\mathrm{M}+\mathrm{H})^{+}$. HRMS (FAB) calcd for $\mathrm{C}_{21} \mathrm{H}_{29} \mathrm{~N}_{2} \mathrm{O} \mathrm{m} / \mathrm{z}: 325.2280(\mathrm{M}+\mathrm{H})^{+}$: found: 325.2279 .

(S)-2-Amino-3-morpholino-1,1-diphenylpropan-1-ol (13d). Light yellow solid (Ether). $130 \mathrm{mg}$, $85 \%$ yield. m.p. $110-113{ }^{\circ} \mathrm{C} .[\alpha]_{\mathrm{D}}{ }^{23}=-66(\mathrm{c}=1.0, \mathrm{EtOH})$. IR (neat) $=3386,3324,2950,1599$, 1449, $1259 \mathrm{~cm}^{-1} .{ }^{1} \mathrm{H}$ NMR (500 MHz, CD $\left.3 \mathrm{OD}\right): \delta 7.29(\mathrm{~d}, J=8.00 \mathrm{~Hz}, 2 \mathrm{H}), 7.18(\mathrm{~d}, J=8.00 \mathrm{~Hz}$, $2 \mathrm{H}), 6.98(\mathrm{t}, J=8.00 \mathrm{~Hz}, 2 \mathrm{H}), 3.76\left(\mathrm{dd}, J_{1}=3.00,9.00 \mathrm{~Hz}, 1 \mathrm{H}\right), 2.20(\mathrm{~s}, 2 \mathrm{H}), 2.10(\mathrm{q}, J=9.00$, $13.00 \mathrm{~Hz}, 1 \mathrm{H}), 1.88(\mathrm{~s}, 2 \mathrm{H}), 1.83(\mathrm{dd}, J=3.00,12.50 \mathrm{~Hz}, 1 \mathrm{H}) .{ }^{13} \mathrm{C}$ NMR $\left(125 \mathrm{MHz}, \mathrm{CD}_{3} \mathrm{OD}\right) \delta$ : 147.6, 146.8, 129.5, 129.3, 127.9, 127.8, 127.2, 126.8, 80.7, 68.2, 61.2, 55.4, 54.6. FAB-MS m/z: $313(\mathrm{M}+\mathrm{H})^{+}$. HRMS (FAB) calcd for $\mathrm{C}_{19} \mathrm{H}_{25} \mathrm{~N}_{2} \mathrm{O}_{2} \mathrm{~m} / \mathrm{z}: 313.1916(\mathrm{M}+\mathrm{H})^{+}$: found: 313.1904 .

(S)-2-Amino-1,1-diphenyl-3-thiomorpholinopropan-1-ol (13e). White solid (Ether). $131 \mathrm{mg}$, $85 \%$ yield. m.p. $94-96{ }^{\circ} \mathrm{C} .[\alpha]_{\mathrm{D}}{ }^{25}=-74(\mathrm{c}=1.09, \mathrm{EtOH}) . \mathrm{IR}($ neat $)=3582,2952,2359,1673,1491$ $\mathrm{cm}^{-1} .{ }^{1} \mathrm{H}$ NMR (500 MHz, CD $\left.3 \mathrm{OD}\right): \delta 7.73(\mathrm{~s}, 1 \mathrm{H}), 7.48(\mathrm{~d}, J=7.50 \mathrm{~Hz}, 2 \mathrm{H}), 7.39(\mathrm{~d}, J=7.50 \mathrm{~Hz}$, $2 \mathrm{H}), 7.20-7.12(\mathrm{~m}, 2 \mathrm{H}), 3.93(\mathrm{~s}, 1 \mathrm{H}), 2.64(\mathrm{~s}, 2 \mathrm{H}), 2.48(\mathrm{~s}, 2 \mathrm{H}), 2.35(\mathrm{~s}, 2 \mathrm{H}), 2.30-2.25(\mathrm{~m}, 3 \mathrm{H})$, $2.12(\mathrm{~d}, J=13.00 \mathrm{~Hz}, 1 \mathrm{H}) .{ }^{13} \mathrm{C} \mathrm{NMR}\left(125 \mathrm{MHz}, \mathrm{CD}_{3} \mathrm{OD}\right): \delta 147.4,146.8,129.5,129.3,127.9$, 127.8, 127.2, 126.2, 126.9, 80.7, 61.5, 57.2, 54.9, 28.9. EI-MS m/z: $328(\mathrm{M})^{+}$. HRMS (EI) calcd for $\mathrm{C}_{19} \mathrm{H}_{24} \mathrm{~N}_{2} \mathrm{OS} \mathrm{m} / \mathrm{z}$ : $328.1609(\mathrm{M})^{+}$: found: 328.1608 . 
General procedure for synthesis of compounds 14a-e. The squaramide mono-ester amide $\mathbf{3}$ (100 $\mathrm{mg}, 1 \mathrm{mmol})$ and $\gamma$-tertiaryamine aminoalcohol $\mathbf{1 3}(1 \mathrm{mmol})$ were charged in sealed tube in $20 \mathrm{~mL}$ $\mathrm{MeOH}$ solvent and the sealed tube was closed tightly without any air gap and the reaction mixture was stirred for $12 \mathrm{~h}$ at $120^{\circ} \mathrm{C}$. After completion of the reaction indicated by TLC, the excess solvent was evaporated under reduced pressure resulted the crude mass, which was purified directly by flash column chromatography using $\mathrm{CHCl}_{3}: \mathrm{MeOH}(9: 1)$ as eluent to give the compound 14a-e (56\% - 81\%).

(S)-3-((3,5-Bis(trifluoromethyl)phenyl)amino)-4-((1-hydroxy-1,1-diphenyl-3-(pyrrolidin-1yl)propan-2-yl)amino)cyclobut-3-ene-1,2-dione (14a). Brown solid (Ether). $99 \mathrm{mg}$, 56\% yield. m.p. $145-146^{\circ} \mathrm{C} .[\alpha]_{\mathrm{D}}{ }^{25}=-45$ (c = 1.0, $\mathrm{CHCl}_{3}$ ). IR (neat): 3566, 3250, 3198, 2965, 1680, $1596 \mathrm{~cm}^{-}$ ${ }^{1} .{ }^{1} \mathrm{H}$ NMR $\left(500 \mathrm{MHz}, \mathrm{CD}_{3} \mathrm{OD}\right): \delta 8.02(\mathrm{~s}, 2 \mathrm{H}), 7.63(\mathrm{~d}, J=8.50 \mathrm{~Hz}, 2 \mathrm{H}), 7.55(\mathrm{t}, J=7.50 \mathrm{~Hz}$, $3 \mathrm{H}), 7.39(\mathrm{t}, J=8.00 \mathrm{~Hz}, 2 \mathrm{H}), 7.26(\mathrm{t}, J=7.50 \mathrm{~Hz}, 1 \mathrm{H}), 7.21(\mathrm{t}, J=7.50 \mathrm{~Hz}, 2 \mathrm{H}), 7.11(\mathrm{t}, J=$ $7.50 \mathrm{~Hz}, 1 \mathrm{H}), 5.45(\mathrm{~d}, J=6.50 \mathrm{~Hz}, 1 \mathrm{H}), 3.00(\mathrm{~d}, J=8.50 \mathrm{~Hz}, 1 \mathrm{H}), 2.77(\mathrm{~s}, 2 \mathrm{H}), 2.60$ (d, $J=13.00$ $\mathrm{Hz}, 1 \mathrm{H}), 2.46$ (s, 2H), 1.78 (s, 4H). ${ }^{13} \mathrm{C}$ NMR (125 MHz, CD $\left.3 \mathrm{OD}\right): \delta$ 186.1, 182.0, 171.6, 164.0, 146.5, 146.3, 142.6, 129.7, 129.2, 128.4, 128.1, 127.0, 126.8, 127.0, 126.8, 125.8, 123.7, 119.2, 116.4, 58.9, 56.0, 24.5. EI-MS m/z: $603(\mathrm{M})^{+}$. HRMS (EI) calcd for $\mathrm{C}_{31} \mathrm{H}_{27} \mathrm{~F}_{6} \mathrm{~N}_{3} \mathrm{O}_{3} \mathrm{~m} / \mathrm{z}: 603.1957$ $(\mathrm{M})^{+}$: found: 603.1948 .

(S)-3-((3,5-Bis(trifluoromethyl)phenyl)amino)-4-((1-hydroxy-1,1-diphenyl-3-(piperidin-1yl)propan-2-yl)amino)cyclobut-3-ene-1,2-dione (14b). Brown solid (Ether). $100 \mathrm{mg}$, 54\% yield. m.p. $125-126^{\circ} \mathrm{C}$.

$[\alpha]_{\mathrm{D}}{ }^{25}=-23.00(\mathrm{c}=1.0, \mathrm{EtOH}) . \mathrm{IR}$ (neat): $3554,3447,1794,1733,1671,1558 \mathrm{~cm}^{-1} .{ }^{1} \mathrm{H}$ NMR $\left(500 \mathrm{MHz}, \mathrm{CD}_{3} \mathrm{OD}\right): \delta 8.02,(\mathrm{~s}, 2 \mathrm{H}), 7.64(\mathrm{~d}, J=7.00 \mathrm{~Hz}, 2 \mathrm{H}), 7.56(\mathrm{~d}, J=9.00 \mathrm{~Hz}, 2 \mathrm{H}), 7.50(\mathrm{~s}$, $1 \mathrm{H}), 7.40(\mathrm{t}, J=8.00 \mathrm{~Hz}, 2 \mathrm{H}), 7.27(\mathrm{t}, J=7.50 \mathrm{~Hz}, 2 \mathrm{H}), 7.11(\mathrm{t}, J=7.50 \mathrm{~Hz}, 1 \mathrm{H}), 5.53(\mathrm{~d}, J=7.50$ $\mathrm{Hz}, 1 \mathrm{H}), 3.17-2.80(\mathrm{~m}, 3 \mathrm{H}), 2.58(\mathrm{~s}, 2 \mathrm{H}), 1.73-1.44(\mathrm{~m}, 4 \mathrm{H}), 1.31-1.25(\mathrm{~m}, 2 \mathrm{H}), 0.88(\mathrm{t}, J=11.00$ $\mathrm{Hz}, 1 \mathrm{H}) .{ }^{13} \mathrm{C}$ NMR $\left(125 \mathrm{MHz}, \mathrm{CD}_{3} \mathrm{OD}\right): \delta 186.1,182.0,171.6,164.2,145.8,142.4,129.9,129.3$, 128.6, 128.3, 127.1, 126.8, 125.8, 123.6, 119.2, 116.7, 81.4, 60.9, 59.4, 56.1, 32.9, 26.0, 23.9, 14.6. FAB-MS m/z: $618(\mathrm{M}+\mathrm{H})^{+}$. HRMS (FAB) calcd for $\mathrm{C}_{32} \mathrm{H}_{30} \mathrm{~F}_{6} \mathrm{~N}_{3} \mathrm{O}_{3} \mathrm{~m} / \mathrm{z}: 618.2191(\mathrm{M}+\mathrm{H})^{+}$: found: 618.2203 .

(S)-3-((3-(Azepan-1-yl)-1-hydroxy-1,1-diphenylpropan-2-yl)amino)-4-((3,5bis(trifluoromethyl)phenyl)amino)cyclobut-3-ene-1,2-dione (14c). Yellow solid (Ether). 117 mg, $62 \%$ yield. m.p. $161-162^{\circ} \mathrm{C} .[\alpha]_{\mathrm{D}}{ }^{23}=-23.00(\mathrm{c}=1.0, \mathrm{EtOH})$. IR (neat): $3522,3493,1793$, $1648 \mathrm{~cm}^{-1} .{ }^{1} \mathrm{H}$ NMR $\left(500 \mathrm{MHz}, \mathrm{CDCl}_{3}\right): \delta 7.93(\mathrm{~s}, 1 \mathrm{H}), 7.64-7.52(\mathrm{~m}, 4 \mathrm{H}), 7.46(\mathrm{~d}, J=6.00 \mathrm{~Hz}$, $2 \mathrm{H}), 7.36(\mathrm{t}, J=7.50 \mathrm{~Hz}, 3 \mathrm{H}), 7.23(\mathrm{t}, J=6.00 \mathrm{~Hz}, 2 \mathrm{H}), 7.17-7.14(\mathrm{~m}, 2 \mathrm{H}), 7.05(\mathrm{t}, J=7.00 \mathrm{~Hz}$, $1 \mathrm{H}), 5.44(\mathrm{~s}, 1 \mathrm{H}), 3.12(\mathrm{~d}, J=14.00 \mathrm{~Hz}, 1 \mathrm{H}), 2.94(\mathrm{~s}, 1 \mathrm{H}), 2.60(\mathrm{~s}, 2 \mathrm{H}), 2.41(\mathrm{~s}, 2 \mathrm{H}), 1.61-1.35$ (m, 8H). ${ }^{13} \mathrm{C}$ NMR $\left(125 \mathrm{MHz}, \mathrm{CDCl}_{3}\right): \delta 182.4,181.7,171.6,162.4,143.6,143.0,139.7,129.2$, $128.8,127.7,127.6,125.2,124.9,124.0,121.9,117.7,116.5,115.3,80.3,59.7,59.3,57.8,54.0$, 
27.1, 26.8, 23.6, 22.5. FAB-MS m/z: $632(\mathrm{M}+\mathrm{H})^{+}$. HRMS (FAB) calcd for $\mathrm{C}_{33} \mathrm{H}_{32} \mathrm{~F}_{6} \mathrm{~N}_{3} \mathrm{O}_{3} \mathrm{~m} / \mathrm{z}$ : $632.2342(\mathrm{M}+\mathrm{H})^{+}$: found: 632.2341 .

(S)-3-((3,5-Bis(trifluoromethyl)phenyl)amino)-4-((1-hydroxy-3-morpholino-1,1diphenylpropan-2-yl)amino)cyclobut-3-ene-1,2-dione (14d). White solid (Ether). $142 \mathrm{mg}, 78 \%$ yield. m.p. $238-240{ }^{\circ} \mathrm{C} .[\alpha]_{\mathrm{D}}{ }^{25}=-8.00(\mathrm{c}=1.10, \mathrm{EtOH})$. IR (neat): 3589, 3423, 1797, 1568, 1541 $\mathrm{cm}^{-1} .{ }^{1} \mathrm{H}$ NMR $\left(500 \mathrm{MHz}, \mathrm{CD}_{3} \mathrm{OD}\right): \delta 8.03(\mathrm{~s}, 2 \mathrm{H}), 7.58(\mathrm{t}, J=7.50 \mathrm{~Hz}, 4 \mathrm{H}), 7.53(\mathrm{~s}, 1 \mathrm{H}), 7.37(\mathrm{t}$, $J=7.50 \mathrm{~Hz}, 2 \mathrm{H}), 7.26-7.21(\mathrm{~m}, 3 \mathrm{H}), 7.11(\mathrm{t}, J=7.00 \mathrm{~Hz}, 2 \mathrm{H}), 5.48(\mathrm{t}, J=4.50 \mathrm{~Hz}, 1 \mathrm{H}), 3.63-3.54$ $(\mathrm{m}, 4 \mathrm{H}), 2.70\left(\mathrm{q}, J_{1}=9.50 \mathrm{~Hz}, 13.50 \mathrm{~Hz}, 3 \mathrm{H}\right), 2.54(\mathrm{~d}, J=12.00 \mathrm{~Hz}, 1 \mathrm{H}), 2.24(\mathrm{~s}, 2 \mathrm{H}) .{ }^{13} \mathrm{C}$ NMR (125 MHz, $\mathrm{CD}_{3} \mathrm{OD}$ ): $\delta 186.3,181.8,171.8,163.4,146.6,146.4,142.6,129.7,129.3,128.4,128.0$, $126.7,125.8,123.7,119.2,116.6,80.8,68.2,61.4,60.0,55.5$. FAB-MS m/z: $620(\mathrm{M}+\mathrm{H})^{+}$. HRMS (FAB) calcd for $\mathrm{C}_{31} \mathrm{H}_{28} \mathrm{~F}_{6} \mathrm{~N}_{3} \mathrm{O}_{4} \mathrm{~m} / \mathrm{z}$ : $620.1984(\mathrm{M}+\mathrm{H})^{+}$: found: 620.1984 .

(S)-3-((3,5-Bis(trifluoromethyl)phenyl)amino)-4-((1-hydroxy-1,1-diphenyl-3-

thiomorpholinopropan-2-yl)amino)cyclobut-3-ene-1,2-dione (14e). White solid (Ether). 151 mg, $81 \%$ yield. m.p. $234-236{ }^{\circ} \mathrm{C} .[\alpha]_{\mathrm{D}}{ }^{25}=-11.00(\mathrm{c}=1.0$, EtOH). IR (neat): $3522,3462,1800$, 1652, $1573 \mathrm{~cm}^{-1} .{ }^{1} \mathrm{H}$ NMR $\left(500 \mathrm{MHz}, \mathrm{CD}_{3} \mathrm{OD}\right): \delta 8.03(\mathrm{~s}, 2 \mathrm{H}), 7.58(\mathrm{t}, J=7.50 \mathrm{~Hz}, 4 \mathrm{H}), 7.53(\mathrm{~s}$, $1 \mathrm{H}), 7.37(\mathrm{t}, J=7.50 \mathrm{~Hz}, 2 \mathrm{H}), 7.26-7.21(\mathrm{~m}, 3 \mathrm{H}), 7.11(\mathrm{t}, J=7.00 \mathrm{~Hz}, 1 \mathrm{H}), 5.46(\mathrm{~m}, 1 \mathrm{H}), 2.91(\mathrm{t}$, $J=7.50 \mathrm{~Hz}, 2 \mathrm{H}), 2.69-2.49(\mathrm{~m}, 8 \mathrm{H}) .{ }^{13} \mathrm{C}$ NMR $\left(125 \mathrm{MHz}, \mathrm{CD}_{3} \mathrm{OD}\right) \delta: 186.2,181.8,171.8,163.4$, 146.7, 146.4, 142.5, 129.7, 126.3, 128.4, 128.0, 126.9, 126.6, 125.8, 123.6, 119.1, 116.6, 80.8, 61.6, 60.3, 57.2, 29.0. FAB-MS m/z: $636(\mathrm{M}+\mathrm{H})^{+}$. HRMS (FAB) calcd for $\mathrm{C}_{31} \mathrm{H}_{28} \mathrm{~F}_{6} \mathrm{~N}_{3} \mathrm{O}_{3} \mathrm{~S} \mathrm{~m} / \mathrm{z}$ : $636.1756(\mathrm{M}+\mathrm{H})^{+}$: found: 636.1760 .

General Procedure for the nitro-aldol reaction. To the stirred solution of isatin 5 ( $20 \mathrm{mg}, 1.0$ equiv.) and catalyst $14 \mathbf{c}$ ( 0.1 equiv.) in THF ( $2 \mathrm{~mL}$ ) was added nitromethane 6 (5.0 equiv.) at 0 ${ }^{\circ} \mathrm{C}$ and stirring was continued for appropriate times at same temperature. After completion of reaction indicated by TLC, the excess solvent was removed under reduced pressure yields the crude mass, which was purified by flash column chromatography using Hexane:EtOAC (6:4) solvent system to give the nitro aldol product as pure compounds. The chemical yields of compound 5 were calculated after isolation by column chromatography. The enantiomeric excess and diastereoselctivity values were determined by chiral HPLC using ChiralPak AD-H and AS-H columns.

(S)-tert-Butyl 3-hydroxy-3-(nitromethyl)-2-oxoindoline-1-carboxylate (7e). Yellow solid. 24 mg, $98 \%$ yield. m.p. $134-136^{\circ} \mathrm{C} .[\alpha]_{\mathrm{D}}{ }^{23}=+2.88(\mathrm{c}=1.0, \mathrm{EtOH})$. The $e e$ was determined by HPLC [DAICEL chiralpak AD-H column, hexane $/ 2$-propanol $=85 / 15$, flow rate: $1.0 \mathrm{~mL} / \mathrm{min}, \operatorname{tr}$ (major) $=10.27 \mathrm{~min}, \operatorname{tr}($ minor $)=17.46 \mathrm{~min}, e e=95 \%] . \mathrm{IR}$ (neat): 3995, 1732, 1616, 1540,1191, $720 \mathrm{~cm}^{-}$ ${ }^{1} .\left({ }^{1} \mathrm{H} \mathrm{NMR}, 500 \mathrm{MHz}, \mathrm{CDCl}_{3}\right): \delta 10.19(\mathrm{~s}, 1 \mathrm{H}), 7.77(\mathrm{t}, J=8.00 \mathrm{~Hz}, 1 \mathrm{H}), 7.66(\mathrm{t}, J=8.00 \mathrm{~Hz}$, $1 \mathrm{H}), 7.44(\mathrm{t}, J=9.00 \mathrm{~Hz}, 1 \mathrm{H}), 7.25-7.19(\mathrm{~m}, 1 \mathrm{H}), 7.08(\mathrm{~s}, 1 \mathrm{H}), 5.22\left(\mathrm{q}, J_{1}=14.00,19.00 \mathrm{~Hz}, 2 \mathrm{H}\right)$, 1.58 (s, 9H). ${ }^{13} \mathrm{C} \mathrm{NMR}\left(125 \mathrm{MHz}, \mathrm{CDCl}_{3}\right): \square \delta 173.5,148.9,140.3,131.2,127.1,125.3,125.0$, 
115.3, 84.7, 78.5, 72.6, 28.4. EI-MS m/z: 308 (M)+. HRMS (EI) calcd for $\mathrm{C}_{9} \mathrm{H}_{8} \mathrm{~N}_{2} \mathrm{O}_{4}$ m/z: 208.0484 $(\mathrm{M}-\mathrm{Boc})^{+}$: found: m/z: $208.0491(\mathrm{M}-\mathrm{Boc})^{+}$.

(S)-3-Hydroxy-5-iodo-3-(nitromethyl)indolin-2-one (7k). Brown solid. $24 \mathrm{mg}$, 97\% yield. m.p. $160-161^{\circ} \mathrm{C} .[\alpha]_{\mathrm{D}}{ }^{21}=+53.33(\mathrm{c}=0.3, \mathrm{EtOH})$. The $e e$ was determined by HPLC DAICEL chiralpak $\mathrm{AD}-\mathrm{H}$ column, hexane/2-propanol $=85 / 15$, flow rate: $1.0 \mathrm{~mL} / \mathrm{min}, \operatorname{tr}(\operatorname{minor})=12.51 \mathrm{~min}$, $\operatorname{tr}($ major $)=16.89 \mathrm{~min}, e e=62 \%]$. IR (neat): 3991, 1730, 1615, 1543, 1182, $825 \mathrm{~cm}^{-1} .{ }^{1} \mathrm{H} \mathrm{NMR}$ $\left(500 \mathrm{MHz}, \mathrm{DMSO}-d_{6}\right): \delta 10.23(\mathrm{~s}, 1 \mathrm{H}), 7.71(\mathrm{~d}, \mathrm{~J}=1.50 \mathrm{~Hz}, 1 \mathrm{H}), 7.57\left(\mathrm{dd}, J_{1}=1.50,8.00 \mathrm{~Hz}\right.$, $1 \mathrm{H}), 6.79(\mathrm{~s}, 1 \mathrm{H}), 6.66(\mathrm{~d}, J=8.0 \mathrm{~Hz}, 1 \mathrm{H}), 5.02\left(\mathrm{q}, J_{1}=8.00,39.50 \mathrm{~Hz}, 2 \mathrm{H}\right) .{ }^{13} \mathrm{C} \mathrm{NMR}(125 \mathrm{MHz}$, DMSO- $\left.d_{6}\right): \delta$ 175.3, 142.4, 138.6, 133.1, 130.7, 112.5, 84.6, 77.8, 72.4; EI-MS m/z: $333.9(\mathrm{M})^{+}$. HRMS (EI) calcd for $\mathrm{C}_{9} \mathrm{H}_{7} \mathrm{~N}_{2} \mathrm{O}_{4} \mathrm{I} \mathrm{m} / \mathrm{z}$ : $333.9450(\mathrm{M})^{+}$: found: 333.9460 .

\section{Acknowledgements}

We thank Adaptable \& Seamless Technology Transfer Program through Target-driven R\&D from Japan Science and Technology Agency (JST) (AS231Z01382G and AS221Z01186D) for partial financial support to this research.

Keywords: squaramide fused amino alcohol $\bullet$ organocatalysts $\bullet$ enantioselective $\bullet$ nitro-aldol • 3-substituted 3-hydroxyoxindoles

[1] a) Bredig, G.; Fiske, P. S. Biochemische Zeitschrift. 1912, 46, 7-13. b) H. Pracejus, Justus Liebigs Annalen der Chemie. 1960, 634, 9-22; c) S. I Yamada, G. Otani. Tetrahedron Lett. 1969, 10, 4237-4240; d) Z. G. Hajos, D. R. Parrish. J. Org. Chem. 1974, 39, 1615-1621.

[2] a) P. I. Dalko in Asymmetric Organocatalysis: A New Stream in Organic Synthesis, in Enantioselective Organocatalysis: Reactions and Experimental Procedures (Eds.: P. I. Dalko), Wiley-VCH Verlag GmbH \& Co. KGaA, Weinheim, Germany. 2007, pp. 1-64; b) C. Bolm, J. A. Gladysz. Chem. Rev. 2003, 103, 2761-2762. c) G. Desimoni, G. Faita, P. Quadrelli. Chem. Rev. 2015, 115, 9922-9980; d) A. H. Cherney, N. T. Kadunce, S. E. Reisman. Chem. Rev. 2005, 115, 9587-9652; e) S. Kobayashi, Y. Mori, J. S. Fossey, M. M. Salte. Chem. Rev. 2011, 111, 2626-2704.

[3] a) U. V. Subba Reddy, M. Chennapuram, C. Seki, Y. Okuyama, E. Kwon, H. Nakano. Eur. J. Org. Chem. 2016, 4124-4143. b) J. Kimura, U. V. Subba Reddy, Y. Kohari, C. Seki, Y. Mawatari, K. Uwai, Y. Okuyama, E. Kwon, M. Tokiwa, M. Takeshita, T. Iwasa, H. Nakano. Eur. J. Org. Chem. 2016, 3728-3756; c) H. Nakano, J. Kumagai, U. V. Subba Reddy, C. Seki, Y. Okuyama, E. Kwon. J. Syn. Org. Chem. 2016, 74, 720-731; d) J. Kumagai, T. Otsuki, U. V. Subba Reddy, Y. Kohari, C. Seki, K. Uwai, Y. Okuyama, E. Kwon, M. Tokiwa, M. Takeshita, H. Nakano. Tetrahedron Asymmetry. 2015, 26, 1423-1439; e) T. Otsuki, J. Kumagai, Y. Kohari, Y. Okuyama, E. Kwon, C. Seki, K. Uwai, Y. Mawatari, N. Kobayashi, 
T. Iwasa, M. Tokiwa, M. Takeshita, A. Maeda, A. Hashimoto, K. Turuga, H. Nakano. Eur. J. Org. Chem. 2015, 7292-7300; f) Y. Kohari, Y. Okuyama, E. Kwon, T. Furuyama, N. Kobayashi, T. Otuki, J. Kumagai, C. Seki, K. Uwai, G. Dai, T. Iwasa, H. Nakano. J. Org. Chem. 2014, 79, 9500-9511; g) Y. Sakuta, Y. Kohari, N. D. M. R. Hutabarat, K. Uwai, E. Kwon, Y. Okuyama, C. Seki, H. Matsuyama, N. Takano, M. Tokiwa, M. Takeshita, H. Nakano. Heterocycles. 2012, 86, 1379-1389; h) C. Suttibut, Y. Kohari, K. Igarashi, H. Nakano, M. Hirama, C. Seki, H. Matsuyama, K. Uwai, N. Takano, Y. Okuyama, K. Osone, M. Takeshita, E. Kwon. Tetrahedron Lett. 2011, 52, 4745-4748; i) H. Nakano, K. Osone, M. Takeshita, E. Kwon, C. Seki, H. Matsuyama, N. Takano, Y. Kohari. Chem. Comm. 2010, 46, $4827-4829$.

[4] Representative reviews on squaramide organocatalysts see. a) R. I. Storer, C. Aciro, L. H. Jones. Chem. Soc. Rev. 2011, 40, 2330-2346. b) J. V. Alegre-Requena. Synlett. 2014, 25, 0298-0299. c) F. R. Wurm, H. -A. Klok. Chem. Soc. Rev. 2013, 42, 8220-8236. d) X. Fang, C.-J. Wang. Chem. Commun. 2015, 51, 1185-1197. e) M. Žabka, R. Šebesta. Molecules. 2015, 20,15500-15524. f) P. Chauhan, S. Mahajan, U. Kaya, D. Hack, D. Enders. Adv. Synth. Catal. 2015, 357, 253-281. g) J. Aleman, A. Parra, H. Jiang, K. A. Jørgensen. Chem. Eur. J. 2011, 17, 6890-6899. h) V. Amendola, G. Bergamaschi, M. Boiocchi, L. Fabbrizzi, M. Milani. Chem. Eur. J. 2010, 16, 4368-4380. i) A. Rouf, C. Tanyeli. Curr. Org. Chem. 2016, 20, 2996-3013. j) F. E. Held, S. B. Tsogoeva. Catal. Sci. Technol. 2016, 6, 645-667.

[5] Representative reviews on nitro-aldol reaction (Henry) see. a) C. Palomo, M. Oiarbide, A. Mielgo. Angew. Chem. Int. Ed. 2004, 43, 5442-5444. b) C. Palomo, M. Oiarbide, A. Laso. Eur. J. Org. Chem. 2007, 2561-2576. c) Y. Alvarez-Casao, E. Marqués-López. R. P. Herrera. Symmetry. 2011, 3, 220-245. d) L. A. Bryant, R. Fanelli. A. J. A. Cobb. Beilstein J. Org. Chem. 2016, 12, 429-443. e) H. Sasai. Comprehensive Organic Synthesis II, 2014, 2, 543-570. f) A. Yu. Sukhorukov, A. A. Sukhanova, S. G. Zlotin. Tetrahedron. 2016, 72, 6191-6281. g) A. Noble. J. C. Anderson. Chem. Rev. 2013, 113, 2887-2939. h) S. Matsunaga. M. Shibasaki. Chem. Commun. 2014, 50, 1044-1057.

[6] Representative reviews on 3-substituted 3-hydroxyoxindoles core moiety see. a) S. Mohammadi, R. Heiran, R. P. Herrera, E. Marqués-López. ChemCatChem. 2013, 5, 21312148. b) M.M.M. Santos. Tetrahedron. 2014, 70, 9735-9757. c) Z.-Y. Cao, Y.-H. Wang, X.P. Zeng, J. Zhou. Tetrahedron Letters. 2014, 55, 2571-2584. d) G. M. Ziarani, R. Moradi, N. Lashgari. Tetrahedron: Asymmetry. 2015, 26, 517-541. e) P. Chauhan, S. S. Chimni. Tetrahedron: Asymmetry. 2013, 24, 343-356. f) W.C. Sumpter. Chem. Rev., 1945, 37, 443479. g) A. Millemaggi R. J. K. Taylor. Eur. J. Org. Chem. 2010, 4527-4547. 
[7] a) D. Seebach, E. W. Colvin, F. Leher, T. Weller. Chimia. 1979, 33, 1-18; b) G. Rosini in Comprehensive Organic Synthesis, Vol. 2 (Eds.: B. M. Trost). 1991, pp. 321-338. c) X.-N. Wang, Y.-Y. Zhang, S. Ye. Adv. Synth. Catal. 2010, 352, 1892-1895.

[8] a) M. Kitajima, I. Mori, K. Arai, N. Kogure, H. Takayama. Tetrahedron Lett. 2006, 47, 31993202; b) Y.-Q. Tang, I. Sattler, R. Thiericke, S. Grabley. Eur. J. Org. Chem. 2001, 261-267; c) M. S. C. Pedras, M. Hossain. Org. Biomol. Chem. 2006, 4, 2581-2590; d) R. G. Mehta, J. Liu, A. Constantinou, M. Hawthorne, J. M. Pezzuto, R. C. Moon, R. M. Moriarty. Anticancer Res. 1994, 14, 1209-1214; e) E. Baur, K. Studler, K. Monde, M. Takasugi. hemoecology 1998, 8, 163-168.

[9] a) L. Liu, S. Zhang, F. Xue, G. Lou, H. Zhang, S. Ma, W. Duan, W. Wang. Chem. Eur. J. 2011, 17, 7791-7795; b) Y. Zhang, Z. J. Li, H. S. Xu, Y. Zhang, W. Wang. RSC Adv. 2011, 1, 389-392; c) M. Q. Li, J. X. Zhang, X. F. Huang, B. Wu, Z. M. Liu, J. Chen, X. D. Li, X. W. Wan. Eur. J. Org. Chem. 2011, 5237-5241; d) P. S. Prathima, K. Srinivas, K. Balaswamy, R. Arundhathi, G. Narsimha Reddy, B. Sridhar, M. Mohan Rao, P. R. Likhar. Tetrahedron Asymmetry 2011, 22, 2099-2103.

[10] a) X. Ni, X. Li, Z. Wang, J. P. Cheng. Org. Lett. 2014, 16, 1786-1789; b) S. R. Kadiyala, R. Pambala, T. Rajiv, L. K. Manepally. Tetrahedron Lett. 2016, 57, 1227-1231; c) Y. B. Han, H. S. Jae, W. L. Ji, B. List, C. E. Song. Angew. Chem. Int. Ed. 2013, 52, 12143-12147; d) I. Atodiresei, C. Vila, M. Rueping. ACS. Catal. 2015, 5,1972-1985.

[11] a) J. P. Malerich, K. Hagihara, V. H. Rawal, J. Am. Chem. Soc. 2008, 130, 14416-14417; b) T. Okino, Y. Hoashi, T. Furukawa, X. N. Xu, Y. Takemoto, J. Am. Chem. Soc. 2005, 127, 119-125; c) L.-X. Zhou, Y.-F. Zhang, L.-M. Wu, J.-Q. Li, J. Mol. Struct. 2000, 516-558, 137.

[12] a) J. V. Alegre-Requena, E. Marqués-López. R. P. Herrera. $R S C \quad A d v ., 2015,5,33450-$ 33462. b) D. Ghosh, N. Gupta, S. H. R. Abdi, S. Nandi, N. H. Khan, R. I. Kureshy, H. C. Bajaj. Eur. J. Org. Chem. 2015, 2801-2806.

[13] The natural bond orbital (NBO) calculation was performed using NBO 3.1 program implemented in the Gaussian 09 package, on the optimized geometries at B3LYP level of theory with 6-31G(d) basis set. 